\title{
ANTIBACTERIAL ACTIVITY OF ANDROGRAPHIS PANICULATA (BURM. F.) METHANOL LEAF EXTRACT ON BACTERIA CONSORTIA ISOLATED FROM BLOOD OF DIABETIC PATIENTS
}

\author{
Lucky Efe Isunu ${ }^{I}$, Fumilola Oluyemi Omoya ${ }^{I}$, Ayodele Oluyemisi Ogundare ${ }^{l}$, Olamide Joshua Babatunde ${ }^{l *}$, Michael Tosin Bayode ${ }^{l}$ \\ and Kehinde Oluyemi Ajayi ${ }^{I}$ \\ Address (es): \\ ${ }^{1}$ Department of Microbiology, Federal University of Technology, P.M.B. 704, Akure, Nigeria; +234 8106768804. \\ *Corresponding author: babatundeoj@ futa.edu.ng \\ https://doi.org/10.36547/be.381
}

ABSTRACT

Introduction: Andrographis paniculata (Burm. f.) is a significant pharmacological plant and regularly used in different parts of the world. The antibacterial activity of the methanol leaf extract of $A$. paniculata against bacterial consortia from blood of diabetic patients was evaluated in this study.

Methods: The enumeration of bacteria from blood samples of diabetic patients and their antibiotic sensitivity pattern were done using standard techniques. The phytochemical analysis of A. paniculata methanol extract and antibacterial assay of the extract were also done using standard methods.

Results: Staphylococcus aureus had the highest occurring rate of $19.56 \%$ while Klebsiella pneumoniae had the lowest occurring rate of $0.40 \%$. The isolates exhibited different sensitivity patterns to conventional antibiotics. There were variations in the zones of inhibition of A. paniculata methanol extract against the bacterial isolates as extract showed concentration was dependent on antibacterial activity with all the bacterial isolates susceptible to the extract. The minimum inhibitory concentration $(\mathrm{mg} / \mathrm{ml})$ of the A. paniculata methanol extract ranged from $5 \mathrm{mg} / \mathrm{ml}$ to $10 \mathrm{mg} / \mathrm{ml}$ while the minimum bactericidal concentration (mg/ml) of the bacteria isolated from diabetic patients ranged from $10 \mathrm{mg} / \mathrm{ml}$ to $20 \mathrm{mg} / \mathrm{ml}$.

Conclusion: Findings revealed that the methanol leaf extract of A. paniculata very strong antibacterial activity for a wide range of bacteria from blood samples of diabetic patients and more reliable than commercially available antibiotics hence suggesting that leaves of $A$. paniculata can be used to develop novel antibacterial drugs.

Keywords: Diabetes, antibiotic, antibacterial, blood, antimicrobial

\section{INTRODUCTION}

The extensive administration of antimicrobial agents to treat diseases continues to lead to the development of antibiotic resistant bacteria, and this is of great concern to the public health (Theuretzbacher, 2020). This study therefore suggested alternative treatment method for diabetic associated bacterial infection using Andrographis paniculata. Andrographis paniculata (Burm. f.) Wall. ex Nees (AP) belonging to the family Acanthaceae is an essential therapeutic plant commonly used around the world. Countries where Andrographis paniculata has been used for therapeutic purposes include Pakistan, Bangladesh, India, China, Hong Kong, Philippines, Malaysia, Indonesia, and Thailand (Chauhan et al., 2019; Kabir $\boldsymbol{e t}$ al., 2014), particularly for the treatment of snake bite, bug bite, diabetes, dysentery and fever. The presence of some phytochemical constituents has been reported to be responsible for its medicinal properties. Radha et al. (2011) reported the antibacterial activity of $A$. paniculata against both gram positive and gram negative bacteria including Staphylococcus aureus, Escherichia coli, Salmonella typhi, Pseudomonas aeruginosa and Streptococcus pyogenes.

Diabetes mellitus (DM), usually referred to simply as diabetes is a group of metabolic disorders in which the blood sugar level remains high over an extended period of time (Balaji et al., 2019). Type 1 DM is as a result of the inability of the pancreas to produce enough insulin, formerly referred to as insulin-dependent diabetes mellitus (IDDM). Type 2 DM occurs as a result of the failure of the cells to respond properly to insulin, and this was formerly referred to as non-insulindependent diabetes mellitus (NIDDM) or adult-onset diabetes (Al-Goblan et al., 2014). The most prominent risk factors have been identified to be excessive body weight and inadequate exercise (Al-Goblan et al., 2014). There exists a third form of diabetes, known as gestational diabetes, and it occurs when a pregnant woman develops high blood sugar level, having to former history of diabetes.

In 2016, it was estimated that about 422 million people had diabetes globally (Zhou et al., 2016; Amiri, 2016), up from an estimated 382 million people in 2013 (Shi and Hu, 2014). Accounting for the ever-changing age structure of the global population, the occurrence of diabetes is $8.5 \%$ among adults, nearly double the rate of $4.7 \%$ in 1980 (WHO, 2016). Type 2 DM makes up about $90 \%$ of the cases (Vos et al., 2012).

Diabetic patients who also have ulcers usually become infected with organisms such as Staphylococcus aureus, Enterococcus, Pseudomonas aeruginosa, Escherichia coli, Klebsiella species and Proteus species (Shankar et al., 2005). Consequently, many drugs have been discovered and used in the treatment of diabetic-associated bacterial infections, however the existing challenge of antibiotic resistance calls for the need to seek alternative trado-medical therapy. This study therefore assessed the antibacterial activity of Andrographis paniculata
(Burm. f.) methanol leaf extract against bacteria isolated from blood of diabetic patients at the University of Medical Sciences Teaching Hospital (formerly State Specialist Hospital), Akure, Nigeria.

\section{MATERIAL AND METHODS}

\section{Collection of plant materials}

The plant material, leaves of Andrographis paniculata were collected at Obakere, The Federal University of Technology, Akure (FUTA), Nigeria where they were growing naturally. The authentication of the plant was done at the Department of Crop, Soil and Pest Management Department Federal University of Technology, Akure, Ondo State, Nigeria.

\section{Collection of blood samples}

The blood samples were collected into EDTA bottles which were labelled with information such as name, sex, age of patient, and date of collection, after which they were transported to the laboratory in an ice pack container for screening for the presence of bacteria.

\section{Isolation of bacteria from the blood samples of diabetes patients}

The isolation and identification of bacteria in the blood of patients were carried out according to the methods of Fawole and Oso (2007) and Cheesbrough (2006). Colonial growth was subcultured into aseptically prepared McConkey agar, mannitol salt agar (MSA) and blood agar and incubated at $35 \pm 2{ }^{\circ} \mathrm{C}$ for a duration of $24 \mathrm{hrs}$ (Florio et al., 2018).

\section{Characterization of bacterial isolates}

The pure culture of each isolate was examined. Microscopic examination, staining techniques and biochemical tests were carried out on the isolates according to the methods described by Olutiola et al. (2000).

\section{Standardization of test bacteria}

A loopful of the bacterial culture was aseptically inoculated into freshly prepared sterile nutrient broth and incubated for 24 hours, after which $0.2 \mathrm{ml}$ was pipetted from the 24 hours old broth culture of the test organism and was dispensed into 20 
$\mathrm{ml}$ sterile nutrient broth and incubated for another 4 hours to standardize the culture to $0.5 \mathrm{McFarland}$ 's standard $\left(10^{6} \mathrm{cfu} / \mathrm{ml}\right)$ before use (Oyeleke et al., 2008).

\section{Antibiotic sensitivity testing}

The antibiotic sensitivity test was performed to investigate the antibiotic sensitivity profile of the microorganisms to different conventional antibiotics using the method described by Bauer et al. (1966). Diameters of zone of inhibition was measured with a calibrated ruler and then compared with Clinical and Laboratory Standards Institute's standard for their sensitivity or resistance (CLSI, 2017). Seeded plates without antibiotic disks served as the control. The antibiotic sensitivity profile was carried out in triplicates.

\section{Preparation of plant extracts}

The air dried sample of Andrographis paniculata were powdered in a table model grinder for extraction. The powdered materials were extracted using methanol. Three hundred gram $(300 \mathrm{~g})$ of the ground samples were weighed into three different containers, and was labelled. Then $2000 \mathrm{ml}$ of the solvents were added, covered, shaken and mixtures were left for about 72 hours, after which the solvents along with the extracts were drained out with muslin cloth, filtered with no 1 Whatman filter paper and semi-solid extracts were obtained in using rotary evaporator (RE-52A Union Laboratories, England).

\section{Phytochemical analysis of $A$. paniculata leaves methanol extract (qualitative)}

The methanol leaf extract of A. paniculata was analysed for the presence or absence of different phytochemicals such as alkaloids, saponin, tannin, phlobatanin, anthraquinone, flavonoid, steroids, terpenoid and cardiac glycosides using standard methods described by AOAC (2011).

\section{Quantitative phytochemical analysis of A. paniculata methanol leaf extract}

\section{Determination of tannin}

To determine the tannin content, the method described by Iwuozor (2019) was used. From the finely ground sample, $1 \mathrm{~g}$ was weighed into $10 \mathrm{ml}$ distilled water and thoroughly shaken. The preparation was allowed to stand for $30 \mathrm{mins}$ at room temperature while stirring was done intermittently at 5 mins interval. After the 30 mins duration, the solution was centrifuged, and the supernatant was obtained. Exactly $2.5 \mathrm{ml}$ of the obtained supernatant was pipetted into $50 \mathrm{ml}$ volumetric flask. Likewise, $2.5 \mathrm{ml}$ of standard tannin acid was dispersed into another $50 \mathrm{ml}$ flask, after which $1 \mathrm{ml}$ Folin-Denis reagent was dispersed into respective flask, which was immediately followed by the addition of $2.5 \mathrm{ml}$ of sodium carbonate $\left(\mathrm{Na}_{2} \mathrm{CO}_{3}\right)$ solution. The resultant solution was diluted and made up to the $50 \mathrm{ml}$ mark of the flask and was thereafter incubated at room temperature for about 90 mins. The absorbance was read at $250 \mathrm{~nm}$ using a UV spectrophotometer and readings were taken with the blank sample at zero.

\section{Determination of total flavonoid}

To determine the total flavonoid content of the extract, the method described by Vuong et al., (2013) was used. This was done by mixing $0.5 \mathrm{ml}$ of the extract with $0.15 \mathrm{ml}$ of $5 \%$ sodium nitrate $\left(\mathrm{NaNO}_{3}\right)$. After $5 \mathrm{mins}, 0.3 \mathrm{ml}$ of aluminum chloride (AlCl3) was added, after which $1 \mathrm{ml}$ of $1 \mathrm{M}$ sodium hydroxide $(\mathrm{NaOH})$ and $2 \mathrm{ml}$ of distilled water were added to the mixture and thoroughly shaken. The absorbance was read using a spectrophotometer at $510 \mathrm{~nm}$.

\section{Determination of saponin}

To determine the saponin content, the spectrophotometric method described by Dan et al., (2009) was used. From the finely grinded sample, $2 \mathrm{~g}$ was weighed into $250 \mathrm{ml}$ beaker and $100 \mathrm{ml}$ of Isobutyl alcohol was added. The mixture was filtered with Whatman filter paper into $100 \mathrm{ml}$ beaker which contained $20 \mathrm{ml}$ of $40 \%$ saturated solution of magnesium carbonate $\left(\mathrm{MgCO}_{3}\right)$. The resultant solution was thereafter filtered with Whatman filter paper. A colourless solution was taken into $50 \mathrm{ml}$ volumetric flask and $2 \mathrm{ml}$ of $5 \%$ iron (III) chloride $\left(\mathrm{FeCl}_{3}\right)$ solution was added to make up with the mark of the distilled water. This setup was allowed to stand for 30 mins for colour development. The absorbance is then read at $380 \mathrm{~nm}$.

\section{Determination of alkaloid}

To determine the alkaloid content, $5 \mathrm{~g}$ of the sample was weighed into a $250 \mathrm{ml}$ beaker and $200 \mathrm{ml}$ of $10 \%$ acetic acid was added and allowed to stand for 4 mins. It was then filtered using Whatman filter paper and the extract was concentrated on a water bath to one quarter of the initial volume. Concentrated ammonium hydroxide was added drop by drop to the extract until precipitation was accomplished. The entire solution was allowed to settle and the precipitate was collected and washed with dilute ammonium hydroxide, and then filtered. The residue was dried and weighed (Harbone, 1973).

\section{Determination of cardiac glycosides}

To determine the cardiac glycosides content, the method described by Sofowora (1996) was employed. From the extract, $10 \mathrm{ml}$ was taken and pipetted into a $250 \mathrm{ml}$ conical flask, after which $50 \mathrm{ml}$ of chloroform was added and shaken on vortex mixer. The resultant solution was filtered into $100 \mathrm{ml}$ conical flask, after which $10 \mathrm{ml}$ of pyridine and $2 \mathrm{ml}$ of $29 \%$ of sodium nitroprusside were added and thoroughly shaken for 10 mins. $3 \mathrm{ml}$ of $20 \% \mathrm{NaOH}$ was added to develop a brownish yellow colour. Glycosides standard (Digitoxin) with concentration ranging from $0-5 \mathrm{mg} / \mathrm{ml}$ were prepared from stick solution and the absorbance was read at $510 \mathrm{~nm}$.

\section{Determination of terpenoid}

To determine the terpenoid content, the method described by Sofowora (1996) was used. From the finely grounded sample, $5 \mathrm{~g}$ was weighed into a $50 \mathrm{ml}$ conical flask, and $20 \mathrm{ml}$ of chloroform/methanol solution in ratio $2: 1$ was added to the sample, shaken thoroughly and then allowed to stand for $15 \mathrm{mins}$ at room temperature. The suspension was centrifuged at 3000rpm. The supernatant was discarded and the precipitate was re-washed with $20 \mathrm{ml}$ of the chloroform/methanol solution in ratio 2:1 and then re-centrifuged. The precipitate was dissolved in $40 \mathrm{ml}$ of $10 \%$ sodium dodecyl sulfate (SDS) solution. $1 \mathrm{ml}$ of $0.01 \mathrm{~m}$ ferric chloride was added and allowed to stand for $30 \mathrm{mins}$ before taking the absorbance at $510 \mathrm{~nm}$.

\section{Determination of steroid}

To determine the steroid, $5 \mathrm{~g}$ of the finely grounded sample was weighed into $100 \mathrm{ml}$ conical flask, followed by the addition of $50 \mathrm{ml}$ of pyridine and the shaken thoroughly for $30 \mathrm{mins}$ at room temperature. $3 \mathrm{ml}$ of $250 \mathrm{mg} / \mathrm{ml}$ copper (I) oxide $\left(\mathrm{Cu}_{2} \mathrm{O}\right)$ and allowed to incubate for $1 \mathrm{hr}$ in the dark and the absorbance was measure at $350 \mathrm{~nm}$ against reagent blank (Sofowora, 1996).

\section{Antibacterial assay of $A$. paniculata methanol extract}

The assay for the antibacterial activity of A. paniculata methanol leaf extract was carried out as described by Geetha et al. (2017) with slight modifications. 1g of the extract was dissolved in 10ml of Dimethyl sulfoxide (DMSO) for reconstitution of the extract. A sterile borer was used to make wells of $5 \mathrm{~mm}$ diameter each on the already solidified Mueller Hinton agar prior to streaking of the plate with the bacterial culture. After the streaking had been completed, $0.1 \mathrm{ml}$ of the extract in peptone water was directly applied to each well on the agar. Positive control was maintained with ciprofloxacin, which is a standard antimicrobial drug, while wells containing the solvent alone were maintained as the negative control. The plates were then incubated for 18 hours at $37^{\circ} \mathrm{C}$ and the diameter of zones of inhibition were measured in $\mathrm{mm}$.

\section{Minimum inhibitory concentration (MIC)}

The MIC assay was performed using tube dilution method with Mueller Hinton broth. A series of broth tubes containing varying concentrations of the $A$. paniculata methanol leaf extract ranging from $5 \mathrm{mg} / \mathrm{ml}$ to $100 \mathrm{mg} / \mathrm{ml}$ were prepared and incubated with standardized density of the test organisms. The lowest concentration of $A$. paniculata extract resulting in no growth following visual inspection after 18-24 hrs of incubation for bacteria using a spectrophotometer was recorded as the MIC.

\section{Minimum bactericidal concentration (MBC)}

The MBC assay was performed using tube dilution method with Mueller Hinton broth. A series of broth tubes containing varying concentrations of the $A$. paniculata methanol leaf extract ranging from $5 \mathrm{mg} / \mathrm{ml}$ to $100 \mathrm{mg} / \mathrm{ml}$ were prepared 
and incubated with standardized density of the test organisms. The lowest concentration of $A$. paniculata extract resulting in no growth following visual inspection after 18-24 hrs of incubation for bacteria using a spectrophotometer was sub-cultured on fresh solid medium and further incubated at $37^{\circ} \mathrm{C}$ for $18-24 \mathrm{hrs}$. The lowest concentration of MIC tubes with no visible bacterial growth on solid medium was regarded as MBC.

\section{Statistical analysis of data}

Data obtained were subjected to one-way analysis of variance while the means were compared by Duncan's New Multiple Range Test at $95 \%$ confidence interval using Statistical Package for Social Sciences version 23.0. Differences were considered significant at $\mathrm{p} \leq 0.05$.

\section{RESULTS AND DISCUSSION}

Rate of occurrence of different bacteria isolated from diabetes patients blood samples

Staphylococcus aureus had the highest percentage positivity of $19.56 \%$ while Klebsiella pneumoniae had the lowest percentage positivity of $0.40 \%$ as shown in Table 1.

The most repeatedly isolated bacteria from blood of diabetic patients was Staphylococcus aureus with highest rate of occurrence of $19.56 \%$. This could be due to the fact that $S$. aureus is one the most common normal flora of human which could find its way into the blood stream of the diabetes patient through the slow healing wound. Rajalakshmi and Amsaveni (2012) reported that common pathogens isolated from the diabetic patients include Staphylococcus aureus, Streptococcus pyogenes, Pseudomonas sp., Escherichia coli, Klebsiella sp. and Proteus sp., an observation which is in accordance with the findings of this study.
Table 1 Rate of occurrence of different bacteria isolated from diabetes patients blood

\begin{tabular}{lcc}
\hline Bacteria & $\begin{array}{c}\text { Number of Patient } \\
\text { tested positive }\end{array}$ & \% Positivity \\
Staphylococcus aureus & 98 & 19.56 \\
Escherichia coli & 80 & 15.97 \\
Salmonella typhi & 81 & 16.17 \\
Streptococcus pyogenes & 73 & 14.57 \\
Streptococcus pneumoniae & 50 & 9.98 \\
Salmonella typhimurium & 49 & 9.78 \\
Pseudomonas aeruginosa & 47 & 9.38 \\
Haemophilus haemolyticus & 11 & 2.20 \\
Haemophilus influenza & 10 & 2.00 \\
Klebsiella pneumonia & 2 & 0.40 \\
Total & 501 & 100.0 \\
\hline
\end{tabular}

Susceptibility patterns of gram negative bacteria isolated from diabetes patients blood

Bacteria isolates were more susceptible to ciprofloaxacin with the zone of inhibition ranged from $8.33 \pm 0.58 \mathrm{~mm}$ (Haemophilus haemolyticus) to $16.33 \pm 0.58 \mathrm{~mm}$ (Salmonella typhi) and were least susceptible to sparfloxacin as shown in Table 2.

\section{Susceptibility patterns of gram positive bacteria isolated from blood of diabetes patient}

The isolates were more susceptible to ciprofloxacin with zone of inhibition ranged from $18.33 \pm 0.58 \mathrm{~mm}$ (Staphylococcus aureus) to $24.33 \pm 0.58 \mathrm{~mm}$ (Streptococcus pneumoniae) and least susceptible to zinnacef with zone of inhibition ranged from $8.67 \pm 0.58 \mathrm{~mm}$ (Staphylococcus aureus) to $17.67 \pm 0.58 \mathrm{~mm}$ (Streptococcus pneumoniae). Staphylococcus aureus was not susceptible to erythromycin and gentamycin as displayed in Table 3.

Table 2 Antibiotic susceptibility pattern of gram negative bacteria isolated from blood samples of diabetes patients

\begin{tabular}{|c|c|c|c|c|c|c|}
\hline Antibiotics & $\begin{array}{c}\text { Salmonella } \\
\text { typhi }\end{array}$ & $\begin{array}{c}\text { Salmonella } \\
\text { typhimurium }\end{array}$ & Escherichia coli & $\begin{array}{c}\text { Pseudomonas } \\
\text { aeruginosa }\end{array}$ & $\begin{array}{c}\text { Haemophilus } \\
\text { influenzae }\end{array}$ & $\begin{array}{l}\text { Haemophilus } \\
\text { haemolyticus }\end{array}$ \\
\hline Ciprofloxacin $(30 \mu \mathrm{g})$ & $16.33 \pm 0.53^{\mathrm{e}}$ & $12.33 \pm 0.58^{\mathrm{d}}$ & $10.67 \pm 0.58^{\mathrm{e}}$ & $14.00 \pm 0.00^{\mathrm{e}}$ & $13.33 \pm 0.57^{\mathrm{f}}$ & $8.33 \pm 0.50^{\mathrm{b}}$ \\
\hline Chloramphenicol (30 $\mu \mathrm{g})$ & $12.33 \pm 0.58^{\mathrm{c}}$ & $14.33 \pm 0.58^{\mathrm{e}}$ & $8.67 \pm 0.42^{\mathrm{d}}$ & $6.33 \pm 0.58^{\mathrm{b}}$ & $12.00 \pm 0.00^{\mathrm{e}}$ & $14.67 \pm 0.58^{\mathrm{d}}$ \\
\hline $\begin{array}{l}\text { Septrin }(30 \mu \mathrm{g}) \\
\text { Amoxillin }(30 \mu \mathrm{g})\end{array}$ & $\begin{array}{c}0.00 \pm 0.00^{\mathrm{a}} \\
12.33 \pm 0.51^{\mathrm{c}}\end{array}$ & $\begin{array}{c}12.00 \pm 0.00^{\mathrm{d}} \\
6.33 \pm 0.58^{\mathrm{b}}\end{array}$ & $\begin{array}{l}6.33 \pm 0.58^{\mathrm{c}} \\
0.00 \pm 0.00^{\mathrm{a}}\end{array}$ & $\begin{array}{c}8.33 \pm 0.58^{\mathrm{c}} \\
12.33 \pm 0.51^{\mathrm{d}}\end{array}$ & $\begin{array}{c}0.00 \pm 0.00^{\mathrm{a}} \\
14.66 \pm 0.58^{\mathrm{g}}\end{array}$ & $\begin{array}{c}8.33 \pm 0.60^{\mathrm{b}} \\
10.33 \pm 0.58^{\mathrm{c}}\end{array}$ \\
\hline 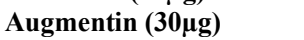 & $12.33 \pm 0.58^{\mathrm{c}}$ & $0.00 \pm 0.00^{\mathrm{a}}$ & $10.00 \pm 0.00^{\mathrm{e}}$ & $8.67 \pm 0.58^{c}$ & $6.33 \pm 0.58^{\mathrm{c}}$ & $4.33 \pm 0.58^{\mathrm{a}}$ \\
\hline Gentamycin $(10 \mu \mathrm{g})$ & $0.00 \pm 0.00^{\mathrm{a}}$ & $8.33 \pm 0.57^{c}$ & $6.67 \pm 0.58^{\mathrm{c}}$ & $4.33 \pm 0.51^{\mathrm{a}}$ & $12.33 \pm 0.58^{\mathrm{e}}$ & $8.33 \pm 0.58^{b}$ \\
\hline Perfloxacin $(30 \mu \mathrm{g})$ & $6.67 \pm 0.58^{b}$ & $8.33 \pm 0.57^{\mathrm{c}}$ & $4.00 \pm 0.00^{\mathrm{b}}$ & $8.33 \pm 0.58^{\mathrm{c}}$ & $10.33 \pm 0.58^{\mathrm{d}}$ & $8.33 \pm 0.58^{b}$ \\
\hline Streptomycin $(30 \mu \mathrm{g})$ & $14.33 \pm 0.52^{\mathrm{d}}$ & $12.33 \pm 0.58^{\mathrm{d}}$ & $6.33 \pm 0.58^{c}$ & $8.00 \pm 0.00^{\mathrm{c}}$ & $4.00 \pm 0.00^{\mathrm{b}}$ & $8.00 \pm 0.00^{\mathrm{b}}$ \\
\hline Tarivid $(10 \mu \mathrm{g})$ & $12.33 \pm 0.50^{\mathrm{c}}$ & $8.00 \pm 0.00^{\mathrm{c}}$ & $4.33 \pm 0.58^{\mathrm{b}}$ & $12.33 \pm 0.53^{\mathrm{d}}$ & $16.33 \pm 0.58^{\mathrm{h}}$ & $8.33 \pm 0.58^{\mathrm{b}}$ \\
\hline Sparfloxacin $(10 \mu \mathrm{g})$ & $6.00 \pm 0.00^{\mathrm{b}}$ & $8.33 \pm 0.58^{c}$ & $4.00 \pm 0.00^{\mathrm{b}}$ & $12.33 \pm 0.58^{\mathrm{d}}$ & $14.33 \pm 0.58^{\mathrm{g}}$ & $8.00 \pm 0.00^{\mathrm{b}}$ \\
\hline
\end{tabular}

Data are presented as Mean \pm S.D $(n=3)$. Values with the same superscript letter(s) along the same column are not significantly different $(\mathrm{p}<0.05)$.

Table 3 Antibiotics susceptibility pattern of gram positive bacteria isolated from blood samples of diabetes patients

\begin{tabular}{|c|c|c|c|}
\hline Antibiotics & $\begin{array}{l}\text { Streptococcus } \\
\text { pneumoniae }\end{array}$ & Staphylococcus aureus & $\begin{array}{c}\text { Streptococcus } \\
\text { pyogenes }\end{array}$ \\
\hline Ciprofloaxacin $(30 \mu \mathrm{g})$ & $24.33 \pm 0.50^{\mathrm{f}}$ & $18.33 \pm 0.58^{\mathrm{g}}$ & $22.33 \pm-0.58^{\mathrm{g}}$ \\
\hline Streptomycin $(30 \mu \mathrm{g})$ & $17.33 \pm 0.58^{\mathrm{b}}$ & $14.33 \pm 0.58^{\mathrm{f}}$ & $18.67 \pm 0.58^{\mathrm{d}}$ \\
\hline Septrin $(30 \mu \mathrm{g})$ & $20.00 \pm 0.00^{\mathrm{c}}$ & $10.33 \pm 0.58^{\mathrm{d}}$ & $19.33 \pm 0.50^{\mathrm{de}}$ \\
\hline Erythromycin $(30 \mu \mathrm{g})$ & $16.33 \pm 0.60^{\mathrm{a}}$ & $0.00 \pm 0.00^{\mathrm{a}}$ & $20.33 \pm 0.58^{\mathrm{f}}$ \\
\hline Perflaxin $(30 \mu \mathrm{g})$ & $21.00 \pm 0.00^{\mathrm{d}}$ & $20.67 \pm 0.61^{\mathrm{h}}$ & $16.00 \pm 0.00^{\mathrm{c}}$ \\
\hline Gentamycin $(10 \mu \mathrm{g})$ & $23.00 \pm 0.00^{\mathrm{e}}$ & $0.00 \pm 0.00^{\mathrm{a}}$ & $12.33 \pm 0.58^{\mathrm{b}}$ \\
\hline Ampiclox (30 $\mu \mathrm{g})$ & $20.33 \pm 0.58^{\mathrm{cd}}$ & $12.33 \pm 0.54^{\mathrm{e}}$ & $18.67 \pm 0.58^{\mathrm{d}}$ \\
\hline Zinnacef $(30 \mu \mathrm{g})$ & $17.67 \pm 0.58^{\mathrm{b}}$ & $8.67 \pm 0.58^{c}$ & $16.33 \pm 0.52^{\mathrm{c}}$ \\
\hline Amoxacillin $((30 \mu \mathrm{g})$ & $20.33 \pm 0.58^{\text {cd }}$ & $6.33 \pm 0.58^{b}$ & $20.00 \pm 0.00^{\mathrm{ef}}$ \\
\hline Rocephin $(25 \mu \mathrm{g})$ & $20.67 \pm 0.58^{\text {cd }}$ & $12.00 \pm 0.00^{\mathrm{e}}$ & $10.33 \pm 0.58^{\mathrm{a}}$ \\
\hline
\end{tabular}

The antibiotic sensitivity profile of bacteria isolated from diabetes patients in this study is analogous with result observed by Vasudeva et al. (2016) who observed appreciable level $(85 \%)$ of Staphylococcus species susceptibility against ciprofloxacin. Similarly, the intermediate susceptibility and resistance of ciprofloxacin and chloramphenicol recorded against E. coli respectively in this study is also in agreement with the findings of Vasudeva et al. (2016) who revealed 33\% sensitivity and $0 \%$ resistance for ciprofloxacin and chloramphenicol against E. coli. 
Qualitative and quantitative phytochemical screening of Andrographis paniculata methanol leaf extract

The phytochemical screening carried out the extract revealed the presence of saponin, tannin, flavonoid, steroid, terpenoid, alkaloid, phytate, oxalate and cardiac glycosides, while phlobatannin and anthraquinone were not detected. This result is presented in table 4 .

Table 4 Qualitative phytochemical screening of Andrographis paniculata leaf extract

\begin{tabular}{lc} 
Component & Presence/Absence \\
Saponin & + \\
Tannin & + \\
Phlobatannin & - \\
Flavonoid & + \\
Steroid & + \\
Terpenoid & + \\
Alkaloid & + \\
Anthraquinone & - \\
Phytate & + \\
Oxalate & + \\
Cardiac glycosides & + \\
\hline
\end{tabular}

Key: $-=$ absent,$+=$ present

The quantitative phytochemical screening carried out on the extract revealed that saponin is the most predominant phytochemical present in the extract with a mean value of $39.7 \pm 2.6 \mathrm{mg} / \mathrm{ml}$ while oxalate is discovered to be the least predominant with a mean value of $1.5 \pm 0.2 \mathrm{mg} / \mathrm{ml}$. This result is shown in figure 1 .

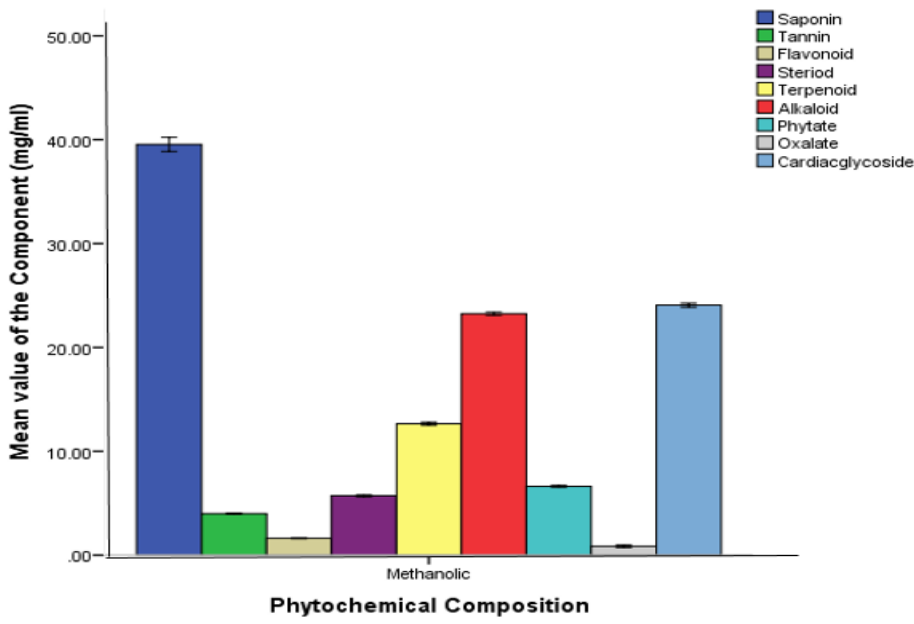

Figure 1 Quantitative phytochemical screening of A. paniculata leaf methanol extract

The result of the qualitative phytochemical analysis of the methanol leaf extract of A. paniculata shown in this study is in agreement with Radha et al. (2011) who also detected the presence of flavonoids, alkaloids, glycosides, steroids, phenols, tannins and saponins in the methanol extract of the plant leaves.

Antibacterial activities (mm) of $A$. paniculata extract against bacteria isolated from diabetes patients blood

There were variations in the zones of inhibition of extract against bacterial isolates, the inhibition of chloramphenicol (control) against the tested bacterial isolates was significantly $(\mathrm{p}<0.05)$ higher than what was observed in the extract. However, extract showed concentration dependent antibacterial activity. Also, all the isolates were susceptible to the extract as illustrated in Table 5.

Table 5 Antibacterial Activities (mm) of A. paniculata Leaves methanol extract against bacteria isolated from diabetes patients blood

\begin{tabular}{|c|c|c|c|c|c|c|c|c|c|}
\hline $\begin{array}{l}\text { Andrographis } \\
\text { paniculata extract }\end{array}$ & A & B & $\mathrm{C}$ & D & $\mathrm{E}$ & $\mathrm{F}$ & G & $\mathrm{H}$ & I \\
\hline $10 \mathrm{mg} / \mathrm{ml}$ & $8.33 \pm 0.58^{\mathrm{a}}$ & $10.33 \pm 0.58^{\mathrm{a}}$ & $8.00 \pm 0.00^{\mathrm{a}}$ & $6.33 \pm 0.47^{\mathrm{a}}$ & $8.33 \pm 0.58^{\mathrm{b}}$ & $5.33 \pm 0.38^{\mathrm{a}}$ & $4.33 \pm 0.58^{\mathrm{a}}$ & $7.33 \pm 0.58^{\mathrm{a}}$ & $8.33 \pm 0.58^{\mathrm{a}}$ \\
\hline $50 \mathrm{mg} / \mathrm{ml}$ & $18.33 \pm 0.61^{\mathrm{b}}$ & $19.67 \pm 0.58^{\mathrm{b}}$ & $20.33 \pm 0.58^{\mathrm{b}}$ & $12.33 \pm 0.68^{\mathrm{b}}$ & $6.33 \pm 0.58^{\mathrm{a}}$ & $12.67 \pm 0.58^{\mathrm{b}}$ & $10.33 \pm 0.58^{b}$ & $14.33 \pm 0.58^{\mathrm{b}}$ & $8.67 \pm 0.52^{\mathrm{a}}$ \\
\hline $100 \mathrm{mg} / \mathrm{ml}$ & $20.00 \pm 0.00^{\mathrm{c}}$ & $21.67 \pm 0.58^{\mathrm{c}}$ & $20.33 \pm 0.58^{\mathrm{b}}$ & $18.00 \pm 0.00^{\mathrm{c}}$ & $16.33 \pm 0.58^{\mathrm{c}}$ & $14.33 \pm 0.58^{\mathrm{c}}$ & $12.00 \pm 0.00^{\mathrm{c}}$ & $16.33 \pm 0.50^{c}$ & $20.33 \pm 0.58^{\mathrm{d}}$ \\
\hline $500 \mathrm{mg} / \mathrm{ml}$ & $22.33 \pm 0.58^{\mathrm{d}}$ & $23.33 \pm 0.58^{\mathrm{d}}$ & $19.67 \pm 0.58^{\mathrm{b}}$ & $20.33 \pm 0.58^{\mathrm{d}}$ & $21.33 \pm 0.58^{\mathrm{d}}$ & $22.00 \pm 0.00^{\mathrm{d}}$ & $18.33 \pm 0.58^{\mathrm{d}}$ & $17.00 \pm 0.00^{\mathrm{c}}$ & $19.33 \pm 0.58^{\mathrm{c}}$ \\
\hline $1000 \mathrm{mg} / \mathrm{ml}$ & $25.33 \pm 0.58^{\mathrm{e}}$ & $24.33 \pm 0.58^{\mathrm{de}}$ & $23.33 \pm 0.58^{\mathrm{c}}$ & $25.67 \pm 0.58^{\mathrm{e}}$ & $23.67 \pm 0.58^{\mathrm{e}}$ & $24.33 \pm 0.58^{\mathrm{e}}$ & $19.33 \pm 0.58^{\mathrm{e}}$ & $22.67 \pm 0.58^{\mathrm{d}}$ & $16.33 \pm 0.33^{\mathrm{b}}$ \\
\hline Chloramphenicol & $26.67 \pm 0.58^{\mathrm{f}}$ & $25.33 \pm 0.50^{\mathrm{e}}$ & $23.33 \pm 0.58^{c}$ & $26.67 \pm 0.55^{\mathrm{f}}$ & $24.67 \pm 0.58^{\mathrm{e}}$ & $27.33 \pm 0.58^{\mathrm{f}}$ & $22.33 \pm 0.58^{\mathrm{f}}$ & $25.00 \pm 0.00^{\mathrm{e}}$ & $20.00 \pm 0.52^{\text {cd }}$ \\
\hline
\end{tabular}

Data are presented as Mean \pm S.D $(n=3)$. Values with the same superscript letter(s) along the same column are not significantly different (p<0.05). Key: A $=$ Streptococcus pneumoniae, $\mathrm{B}=$ Staphylococcus aureus, $\mathrm{C}=$ Streptococcus pyogenes, $\mathrm{D}=$ Salmonella typhi, $\mathrm{E}=$ Salmonella typhimurium, $\mathrm{F}=$ Esherichia coli, $\mathrm{G}=$ Pseudomonas aeruginosa, $\mathrm{H}=$ Haemophilus influenzae, $I=$ Haemophilus haemolyticus

The antibacterial activity of Andrographis paniculata methanol leaf extract documented in this study might be due to the presence of the observed phytochemical constituents which include saponin, tannin, flavonoid, steroid, terpenoid, alkaloids, phytate, oxalates and cardiac glycosides as reported by Nwanjo and Alumanah, (2006). The result of the bacterial assay of methanol extract of A. paniculata is also in line with Shalini and Narayanan (2015) who observed the antibacterial activity of the extract against selective human pathogens such as Staphylococcus aureus, Escherichia coli, Salmonella typhi and Pseudomonas aeruginosa. Among the different solvents employed in their study, methanol extract showed greater antibacterial activity against E. coli, S. typhi, $P$. aeruginosa and $S$. aureus. Dada-Adegbola et al. (2014) observed antibacterial activity of methanol extract of A. paniculata against S. aureus, E. coli, S. typhi, P. aeruginosa as Radha et al. (2011) also revealed the antibacterial proficiency of the methanol extract of A. paniculata against S. pyogenes.

Minimum inhibitory and minimum bactericidal concentration $(\mathrm{mg} / \mathrm{ml})$ of $A$. paniculata leaves methanol extract against bacteria isolated from diabetes patients

The minimum inhibitory concentration $(\mathrm{mg} / \mathrm{ml})$ of the A. paniculata methanol extract range from $5 \mathrm{mg} / \mathrm{ml}$ to $10 \mathrm{mg} / \mathrm{ml}$ while the minimum bactericidal concentration $(\mathrm{mg} / \mathrm{ml})$ of A paniculata methanol leaf extract against bacteria isolated from diabetes patient range from $10 \mathrm{mg} / \mathrm{ml}$ to $20 \mathrm{mg} / \mathrm{ml}$ as shown in a Table 6.

Table 6 Minimum inhibitory and minimum bactericidal concentration $(\mathrm{mg} / \mathrm{ml})$ of Andrographis paniculata leaves methanol extract against bacteria isolated from diabetes patients blood

\begin{tabular}{lcc}
\hline Bacterial isolates & MIC $(\mathbf{m g} / \mathbf{m l})$ & MBC $(\mathbf{m g} / \mathbf{m l})$ \\
Salmonella typhi & 10 & 10 \\
Haemophilus influenza & 10 & 10 \\
Klebsiella pneumoniae & 5 & 10 \\
Staphylococcus aureus & 5 & 10 \\
Salmonella typhimurium & 5 & 50 \\
Esherichia coli & 5 & 10 \\
Pseudomonas aeruginosa & 5 & 10 \\
\hline
\end{tabular}

Key: $\mathrm{MIC}=$ Minimum Inhibitory Concentration, $\mathrm{MBC}=$ Minimum Bactericidal Concentration 
The result of the minimum inhibitory concentration (MBC) of A. paniculata observed in this study is in agreement with Banerjee et al., (2017) who revealed the antibacterial property of andrographolide; a bioactive ingredient of the methanol extract of A. paniculata against some gram negative organisms implicated in blood samples of diabetes patients including; E. coli, P. aeruginosa, S. typhimurium, $H$. influenzae, and Klebsiella pneumoniae with two gram positive bacteria organisms also common with blood specimens of diabetes patients like $S$. aureus and S. pnenmoniae.

\section{CONCLUSION}

From the result, it was revealed that the methanol leaf extract of A. paniculata showed strongest antimicrobial activity for a wide range of bacterial pathogens from diabetes patients blood samples and also more reliable than commercially available antibiotics. Therefore, the result suggests that the leaves of A. paniculata possess potential properties and bioactive ingredients in the search for novel antidiabetes drugs. Further studies on the Andrographis paniculata leaves should be carried out to augment the pharmacological and phytochemical proficiency to find new bioactive compounds as well as conservation of this plant.

Acknowledgments: The authors hereby acknowledge the Department of Crop, Soil and Pest Management, FUTA, for helping to authenticate the plant material used for the study and the laboratory staff of the University of Medical Sciences Teaching Hospital, Akure for the role they played during the collection of the blood samples, and the ethical committee of the Ondo State Ministry of Health for providing the ethical clearance for the research study.

Authors' Contributions: FOO designed the study. FOO and AOO jointly supervised the study. LEI developed the methodology and acquired the data. KOA performed the analysis and interpretation of data. OJB and MTB wrote the first draft of the manuscript and managed literature search. FOO and AOO reviewed and revised the manuscript. All authors read and approved the final manuscript.

\section{REFERENCES}

Al-Goblan, A. S., Al-Alfi, M. A., \& Khan, M. Z. (2014). Mechanism linking diabetes mellitus and obesity. Diabetes, metabolic syndrome and obesity: targets and therapy, 7, 587.

Amiri, M. (2016). Diabetes mellitus type 2; an international challenge. Annals of Research in Dialysis, $\mathbf{1}(1)$.

AOAC, (2011). Laboratory Manual on Basic Methods in Analytical Chemistry Education Consult. 22 ${ }^{\text {nd }}$ edition, In: Official Methods of Analysis. 25-27.

Balaji, R., Duraisamy, R., \& Kumar, M. P. (2019). Complications of diabetes mellitus: A review. Drug Invention Today, 12(1).

Banerjee, M., Parai, D., Chattopadhyay, S., \& Mukherjee, S. K. (2017). Andrographolide: antibacterial activity against common bacteria of human health concern and possible mechanism of action. Folia Microbiologica, 62(3), 237-244. https://doi.org/10.1007/s12223-017-0496-9

Bauer, A. W., Kirby, W. M. M., Sherris, J. C., \& Turck, M. (1966). Antibiotic Susceptibility Testing by a Standardized Single Disk Method. American Journal of Clinical Pathology, 45(4_ts), 493-496. https://doi.org/10.1093/ajcp/45.4 ts.493 Chauhan, E. S., Sharma, K., \& Bist, R. (2019). Andrographis paniculata: A Review of its Phytochemistry and Pharmacological Activities. Research Journal of Pharmacy and Technology, 12(2), 891. https://doi.org/10.5958/0974360x.2019.00153.7

Clinical Laboratory Standard Institute (CLSI) (2017). Performance Standards for antimicrobial susceptibity tests. Document M100-517. CLSI, Wagne, PA. Clinical Microbiology; 45(1):199-205

Dada-Adegbola, H. O., Olajide, O., \& Ajayi B. (2014). Comparative study of antibacterial activity of juice, acetone, methanol and ethanol leaf extract of Andrographis paniculata (King of Bitters). Journal of Medical Research, 3(1): 006-012.

Dan, M., Xie, G., Gao, X., Long, X., Su, M., Zhao, A., Zhao, T., Zhou, M., Qiu, Y., \& Jia, W. (2009). A rapid ultra-performance liquid chromatographyelectrospray Ionisation mass spectrometric method for the analysis of saponins in the adventitious roots ofPanax notoginseng. Phytochemical Analysis, 20(1), 6876. https://doi.org/10.1002/pca.1099

Fawole, M. O., \& Oso, B. A. (2007). Laboratory Manual of. ISSN 1597-6343 Published by Faculty of Science, Kaduna State University.

Florio, W., Morici, P., Ghelardi, E., Barnini, S., \& Lupetti, A. (2018). Recent advances in the microbiological diagnosis of bloodstream infections. Critical reviews in microbiology, 44(3), 351-370.
Geetha, I. and Catherine, P. A. S. (2017). Antibacterial activity of Andrographis paniculata extracts. The Pharma Innovation Journal, 6(5): 01-04

Harbone, J. B. (1973) Phytochemical methods. A Guide to Modern Technique of plant Analysis. Chapman and Hall, New York, 278.

Iwuozor, K. O. (2019). Qualitative and Quantitative Determination of AntiNutritional Factors of Five Wine Samples. Advanced Journal of Chemistry-Section A, 2(2), 136-146. https://doi.org/10.29088/SAMI/AJCA.2019.2.136146

Kabir, M. H., Hasan, N., Rahman, M. M., Rahman, M. A., Khan, J. A., Hoque, N. T., Bhuiyan, M. R. Q., Mou, S. M., Jahan, R., \& Rahmatullah, M. (2014). A survey of medicinal plants used by the Deb barma clan of the Tripura tribe of Moulvibazar district, Bangladesh. Journal of Ethnobiology and Ethnomedicine, 10(1). https://doi.org/10.1186/1746-4269-10-19

Nwanjo, H., \& Alumanah, E. (2006). Effect of aqueous extract of Gongronema latifolium on some indices of liver function in rats. Global Journal of Medical Sciences, 5(1). https://doi.org/10.4314/gjms.v5i1.10142

Olutiola, P. O., Famurewa, O. and Sonntag, H. G. (2000). An introduction to general microbiology. A Practical Approach. Hygiene Institute per Universal Heidelberg Federal Republic Germany. 157-175

Oyeleke, S. B., Dauda, B. E. N., \& Boye, O. A. (2008). Antibacterial activity of Ficus capensis. African Journal of Biotechnology, 7(10).

Radha, R., Sermakkani, M., \& Thangapandian, V. (2011). Evaluation of phytochemical and antimicrobial activity of Andrographis paniculata nees (Acanthaceae) aerial parts. International journal of Pharmacy and life sciences, 2(2), 562-567.

Rajalakshmi, V., \& Amsaveni, V. (2012). Antibiotic susceptibility of bacterial pathogens isolated from diabetic patients. International Journal of Microbiological Research, 3(1), 30-32.

Shalini, V. B., \& Narayanan, J. S. (2015). Antibacterial activity of Andrographis paniculata Nees against selective human pathogens. African Journal of Microbiology Research, 9(16), 1122-1127.

Shankar, E. M., Mohan, V., Premalatha, G., Srinivasan, R. S., \& Usha, A. R. (2005). Bacterial etiology of diabetic foot infections in South India. European Journal of Internal Medicine, 16(8), 567-570. https://doi.org/10.1016/j.ejim.2005.06.016

Shi, Y., \& Hu, F. B. (2014). The global implications of diabetes and cancer. The Lancet, 383(9933), 1947-1948. https://doi.org/10.1016/s0140-6736(14)60886-2 Sofowora, A. (1996). Research on Medicinal Plants and Traditional Medicine in Africa. The Journal of Alternative and Complementary Medicine, 2(3), 365-372. https://doi.org/10.1089/acm.1996.2.365

Theuretzbacher, U., Outterson, K., Engel, A., \& Karlen, A. (2020). The global preclinical antibacterial pipeline. Nature Reviews Microbiology, 18(5), 275-285.

Vasudeva, N., Nirwan, P. S., \& Shrivastava, P. (2016). Bloodstream infections and antimicrobial sensitivity patterns in a tertiary care hospital of India. Therapeutic Advances in Infectious Disease, 3(5), 119-127. https://doi.org/10.1177/2049936116666983

Vos, T., Flaxman, A. D., Naghavi, M., Lozano, R., Michaud, C. and Ezzati, M. (2012). Years lived with disability (YLDs) for 1160 sequelae of 289 diseases and injuries 1990-2010: a systematic analysis for the Global Burden of Disease Study 2010. Lancet. 380(9859): 2163-96

Vuong, Q. V., Hirun, S., Roach, P. D., Bowyer, M. C., Phillips, P. A., \& Scarlett, C. J. (2013). Effect of extraction conditions on total phenolic compounds and antioxidant activities of Carica papaya leaf aqueous extracts. Journal of herbal medicine, 3(3), 104-111.

World Health Organization. (2016). Global report on diabetes. Geneva, Switzerland. World Health Organization, 1-88.

Zhou, B., Lu, Y., Hajifathalian, K., Bentham, J., Di Cesare, M., Danaei, G., ... \& Gaciong, Z. (2016). Worldwide trends in diabetes since 1980: a pooled analysis of 751 population-based studies with 4.4 million participants. The Lancet, 387(10027), 1513-1530. 